\title{
The Study of Resistance of Cement Composites against Microbial Attack
}

\author{
Estokova Adriana ${ }^{1}$, Ondrejka Harbulakova Vlasta $^{1}$, Luptakova Alena ${ }^{2}$, Prascakova Mária ${ }^{2}$ and Stevulova \\ Nadezda $^{1}$ \\ 1. Institute of Building and Environmental Engineering, Faculty of Civil Engineering, Technical University of Kosice, Slovakia \\ 2. Institute of Geotechnics, Slovak Academy of Science, Slovakia
}

\begin{abstract}
The start and the course of bio-corrosion are conditioned by many factors which include biological effects like the influence of vegetation and microorganisms causing the deterioration of materials. The influence of bacteria causing the deterioration of concrete has been linked to the generation of biogenic sulphuric and nitric acids which originate in corrosion process by dissolution of calcium containing minerals from the concrete matrices. This paper primarily focuses on the investigation of influence of sulphur-oxidising bacteria Acidithiobacillus thiooxidans and sulphate-reducing bacteria Desulfovibrio desulfuricans at the resistance degree of cement composites. Various concrete composites with $5 \%$ addition of black coal fly ash as cement replacement as well as the reference samples without coal fly ash addition were studied in the experiments. The laboratory experiments as well as experiments in situ in real environments of sewage system proceeded during 90 days. The corrosion was manifested by surface changes and weight changes of cement composites samples as well as changes in $\mathrm{pH}$ values of leachates. Considerable surface changes were detected in all investigated samples by microscopic methods. Crystals precipitated on concrete samples surface were identified by EDX as mixture of gypsum and ettringite. The roughness increases of surface of cement composites were determined by confocal laser scanning microscopy.
\end{abstract}

Key words: Concrete, MIC, bacteria, biocorrosion, biodeterioration.

\section{Introduction}

The durability of inorganic materials is significantly affected by many biological activities and interactions. Biodeterioration can be regarded as the irreversible loss of value and/or information of objects of art made of mineral materials caused by attack of living organisms [1]. However, the mere presence of macro-and microorganisms is not sufficient when considering the cause of decay, because they can use and/or enhance the deterioration mechanisms only in particular conditions and when also other factors occur [2]. Prominent example of the impact of biological system on material can be seen in the interaction between the organisms employed in a process of the microbial deterioration of concrete in sewage systems

Corresponding author: Estokova Adriana, $\mathrm{PhD}$, associate professor, research fields: chemistry, environmental engineering. E-mail: adriana.estokova@tuke.sk. caused by microbial excretions [3]. The microflora on building materials represents a complex ecosystem which develops in various ways depending on environmental conditions and the physico-chemical properties of the material in question. Microorganisms can be divided into the following groups [4]: photolithoautotrophic organisms, such as algae, cyanobacteria, mosses and higher plants, which use sunlight as energy source, and release oxygen during photosynthesis. Their carbon requirements are met by binding $\mathrm{CO}_{2}$ from atmosphere. The second group are chemolithoautotrophic bacteria which use inorganic compounds (e.g., ammonia, nitrites, hydrogen sulfide, thiosulfates of elemental sulfur) to obtain energy from their oxidation and bind $\mathrm{CO}_{2}$ from the atmosphere. This process results in the release of nitrous acids (e.g., Nitrosomonas spp.), nitric acid (e.g., Nitrobacter spp.) or sulfuric acid (e.g., Acidithiooxidans) [5]. 
High numbers of strictly autotrophic Acidithiobacillus have been found not only under the surfaces of highly deteriorated stones which presented a pulverizing aspect, but also on deeper layers where there was no stone decay yet. Stone anaerobic species, like Desulfovibrio desulfuricans, are not strictly autotrophic and can sometimes utilize organic compound as electron donors. They can find sulfate from air pollutants and produce hydrogen sulfide by the reaction (1) [6]:

$$
\text { Organic acid }+\mathrm{SO}_{4}{ }^{2-} \rightarrow \mathrm{H}_{2} \mathrm{~S}+\mathrm{CO}_{2}
$$

This product is highly corrosive acid and on open air surface its salts provoke the formation of black and/or grey films and crusts often described as patina [6].

The properties as well as the mechanisms responsible for deterioration of building materials such as concrete, mortars, composites, timber, gypsum, etc., are modified by different kind of bacteria [7]. Even though concrete as one of the basic construction materials is strongly resistant to aggressive environment; it does corrode mainly because of the conditions influences in exterior. On one hand, corrosion can be initiated by some reaction of constituents used in the production of concrete (type and properties of cement, aggregate, quality of water, or even additions and admixtures) and on the other hand, it depends on technology and procedures used in concrete manufacturing as well as on its maintenance and actual use of the product.

Additives and admixtures are used to improve the properties of the concrete. Fly ash can be one of the admixtures and it is used to influence the properties of new or hardened concrete or to gain some special features [8].

The fly ash can be used as a cement replacement; it also might be used as inactive filler (additive type I) [9], without any effect on cement dosage [8]. Despite of the fact that fly ash is essentially a waste material (and as such it might present different chemical, mineral, grading composition which all depend on the type of the coal, type of furnace, the combustion process and separation), it still needs to be in accordance with the
Slovak Standards STN EN 206-1, STN EN 450 and STN EN 12620.

In the case of structures, it works positively with the processes of hardening, including the setting heat formation and reducing the risks of reversible shrinkage of the concrete; enhances the resistance of concrete to aggressive environment; improves impermeability of hardened concrete surface layer against pressure water effect; retards of the carbonization processes of concrete surface [8].

Before the corrosion process can begin, the conversion of sulfate present in the sewage system to hydrogen sulfide must occur. This conversion is performed by sulphate-reducing bacteria (SRB). The $\mathrm{H}_{2} \mathrm{~S}$ generated by sulfate reducing bacteria in biofilms partitions into the headspace of the collections system. The $\mathrm{H}_{2} \mathrm{~S}$ then repartitions into the condensate layer on the exposed surface of the concrete and is converted to various partially reduced sulfur compounds. With presence of oxygen and moisture, sulfur-oxidizing bacteria convert these reduced sulfur compounds to sulfuric acid. The sulfuric acid reacts with the binder in the concrete, thus producing ettringite and gypsum [10]. The formation of ettringite $\left(3 \mathrm{CaO} \cdot \mathrm{Al}_{2} \mathrm{O}_{3} \cdot 3 \mathrm{CaSO}_{4} \cdot 32 \mathrm{H}_{2} \mathrm{O}\right)$ during the acid reaction process causes major problems because it is expansive and leads to internal cracking and pitting which provides larger surface area for the chemical reaction to occur. It is also responsible for providing further sites of penetration of the acid into the concrete [11].

The experiment of biocorrosion took place in both laboratory conditions and in situ environment with waste-water. The results as weight changes of concrete samples, the roughness of surfaces and images of SEM and EDX analysis were compared and presented in this paper.

\section{Methods}

The investigation of cement composites resistance against the microorganism attack proceeded under model conditions in laboratory as well as under real conditions-experiments in situ in the sewage system. 


\subsection{Concrete Samples}

The cement composite samples with 5\% addition of black coal fly ash as cement replacement, as well as reference samples without coal fly ash addition were investigated in experiments. The concrete samples used for the experiments were prepared in accordance with Slovak standard STN EN 206-1 using cement CEM I $42.5 \mathrm{R}$. The composition of the reference samples can be found in Table 1 .

The concrete samples with addition of coal fly ash were prepared in the same way, but $5 \%$ of the amount of cement was replaced by coal fly ash. The used coal fly ash of volumetric weight of $2381 \mathrm{~kg} / \mathrm{m}^{3}$ originates from the process of burning of black coal in Košice city heating plant (Teplaren Kosice a.s. TEKO, Slovakia). The chemical composition of used coal fly ash can be seen in Table 2.

Prepared concrete samples were compression tested and categorized as class C30/37. The cubic concrete samples $(150 \times 150 \times 150 \mathrm{~mm})$ have been drilled by drilling mechanism STAM in cylindrical shape with diameter of $50 \mathrm{~mm}$ and height of $30 \mathrm{~mm}$. The drilled samples were autoclaved at $120^{\circ} \mathrm{C}$ to constant weight and dried at $60^{\circ} \mathrm{C}$ before being used in experiments.

\subsection{Experiments in Situ}

Table 1 The composition of the reference samples.

\begin{tabular}{|l|l|}
\hline Component & $\begin{array}{l}\text { Mass concentration } \\
\left(\mathrm{kg} / \mathrm{m}^{3} \text { of concrete) }\right.\end{array}$ \\
\hline Aggregate fraction 0/4 & 737 \\
\hline Aggregate fraction 4/8 & 184 \\
\hline Aggregate fraction 8/16 & 909 \\
\hline Cement 42.5 R & 410 \\
\hline Water & 168 \\
\hline Super plasticizer Murasan BWA 14 & 2.7 \\
\hline Air entraining admixture Berapor G & 3.3 \\
\hline
\end{tabular}

The three samples with 5\% replacement of cement by coal fly ash and the three reference samples without coal fly ash addition were inserted into waste-water sewer pipes in the city of Kosice, Slovakia. The waste-water parameters were tested in Labs of Waste-water in Koksov Baksa, East Slovakian Water Company in Kosice. The measured average value of waste-water was 7.42 and both the physical and chemical analyses of waste-water were published in our previous paper [12].

The microbiological analysis of waste-water confirmed the presence of bacteria Desulfovibrio desulfuricans and Ac. thiooxidans as major concrete biodeteriogens.

The concrete samples were partially inserted or not depending on the amount of waste-water flowing through the sewer pipes. After 90 days of experiment, the samples were cleaned of waste-water sediment, autoclaved at $120^{\circ} \mathrm{C}$ to constant weight and dried at $60^{\circ} \mathrm{C}$.

\subsection{Laboratory Experiments}

Concrete biodeterioration study proceeded in a laboratory reactor by simultaneous effect of sulphate-reducing bacteria (SRB) and sulphur-oxidising bacteria during 90 days at constant temperature of $25^{\circ} \mathrm{C}$.

\subsubsection{Microorganisms}

In the model experiment, sulphate-reducing bacteria (SRB) genera Desulfovibrio spp. and sulphur-oxidising bacteria genera Ac. thiooxidans were used. Sulphatereducing bacteria (SRB) Desulfovibrio desulfuricans used in the experiment were isolated from a mixed culture obtained from the potable mineral water (Gajdovka spring, the locality Kosice-north, Slovakia). The selective nutrient medium DSM-63 [13] was used.

Table 2 Chemical composition of coal fly ash used in cement composites.

\begin{tabular}{llllllllllll}
\hline Chemical component & $\mathrm{SiO}_{2}$ & $\mathrm{Al}_{2} \mathrm{O}_{3}$ & $\mathrm{Fe}_{2} \mathrm{O}_{3}$ & $\mathrm{TiO}_{2}$ & $\mathrm{CaO}$ & $\mathrm{MgO}$ & $\mathrm{K}_{2} \mathrm{O}$ & $\mathrm{MnO}$ & $\mathrm{Pb}_{2} \mathrm{O}_{3}$ & $\mathrm{~S}_{\text {tot }}$ \\
\hline Percentage (\%) & 36.6 & 16.06 & 10.82 & 0.65 & 3.3 & 1.22 & 1.41 & 0.27 & 0.56 & 0.09 \\
\hline
\end{tabular}


The optimal growth for thermofilic SRB bacteria was ensured by pH 6.5 and temperature of $60^{\circ} \mathrm{C}$.

Sulphur-oxidising bacteria genera Ac. thiooxidans were isolated from the mixed culture obtained from the mine water (the shaft Pech, the locality Smolník, Eastern Slovakia) and the selective nutrient medium 9K [14] were used for the isolation and cultivation of these bacteria. The optimal growth temperature for these strictly autotrophic bacteria (about 1.0-2.0 $\mu \mathrm{m}$ length and $0.5 \mu \mathrm{m}$ in width) that oxidise sulphur and thiosulphate to sulphuric acid is $30^{\circ} \mathrm{C}$ and the $\mathrm{pH}$ value is 2.5 .

\subsubsection{Laboratory Apparatus}

The laboratory apparatus was supposed to simulate the real conditions in sewage pipes. Three concrete samples with 5\% replacement of cement by coal fly ash and three reference samples without coal fly ash addition were placed into the reactor and the lower parts of concrete samples were immersed into waste-water from sewer pipes with waste-water in Košice city.

During their growth, the sulphate-reducing bacteria Desulfovibrio spp. continuously produced a large amount of hydrogen sulphide into laboratory reactor that assures the maintenance of anaerobiosis. The residual hydrogen sulphide was taken away from the reactor into the trap filled with cadmium acetate solution and mutually joined with the reactor.

The top of concrete samples in the reactor was inoculated by sulphur-oxidising bacteria Ac. thiooxidans in periodical time intervals once a week. Ac. thiooxidans as strictly autotrophic bacteria oxidises the dissolved hydrogen sulphide and other sulphur compounds to sulphuric acid which causes the corrosion of concrete.

\subsection{Biodeterioration Characterising Methods}

Concrete surface changes were observed by electron scanning microscopy (SEM) with the equipment Jeol JSM-35CF (Japan). The elemental EDX analyses were carried out on the micro-analytical system LINK AN
10000 operating in the secondary mode at a potential $25 \mathrm{kV}$ and at various extensions from 90 to 5500. The roughness measurements were investigated by confocal laser scanning microscope (CLSM) Lext OLS3000 in cooperation with the Klokner Institute CTU in Prague in the department of experimental and measurement methods. The weight changes of concrete samples after both experiments were determined by gravimetric method measured by analytical balance within $0.00001 \mathrm{~g}$.

$\mathrm{pH}$ changes of waste-water used in laboratory experiment were evaluated as differences between initial $\mathrm{pH}$ and final $\mathrm{pH}$ after the experiment by $\mathrm{pH}$ meter $\mathrm{PHH}-3 \mathrm{X}$ Omega.

\section{Results and Discussion}

\subsection{The Surface Changes}

The significant surface changes were observed after 90 days for all investigated concrete samples in both the laboratory and in situ experiments. The concrete samples were significantly eroded and some gravel components were completely removed. The new surface products were also observed and investigated by electron microscopy. Illustration of precipitated products can be seen in Fig. 1. The presence of gypsum $\mathrm{CaSO}_{4} \cdot 2 \mathrm{H}_{2} \mathrm{O}$ and ettringit $3 \mathrm{CaO} . \mathrm{Al}_{2} \mathrm{O}_{3} \cdot 3 \mathrm{CaSO}_{4} \cdot 32 \mathrm{H}_{2} \mathrm{O}$ (Fig. 2) as a surface precipitated product was confirmed by EDX in both the laboratory and in situ experiments in accordance with Ref. [15]. No significant differences related to the surface products chemical composition were observed between the samples with 5\% replacement of cement by coal fly ash and the reference samples without coal fly ash addition in the laboratory experiments. The other investigation of precipitate products for in situ tested samples is still in progress.

The significant changes of surface roughness have been observed for all samples after biocorrosion experiments by confocal laser microscopy. The most important roughness characteristics Rt (maximum profile roughness curve) and Ra (arithmetical mean 

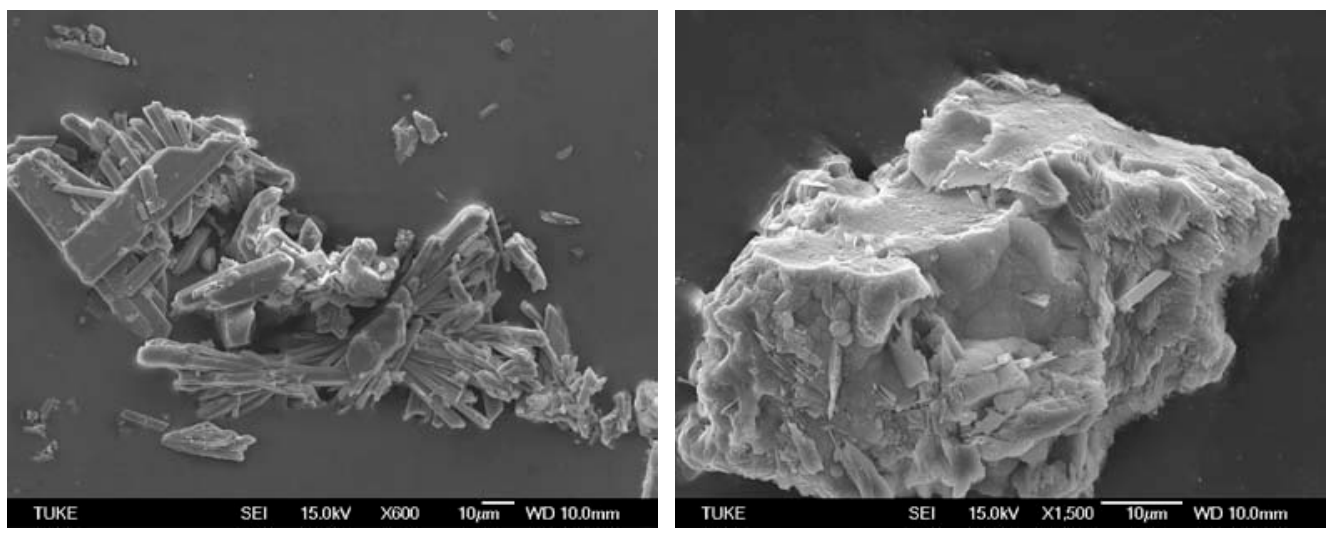

Fig. 1 SEM micrographs of the new surface products.

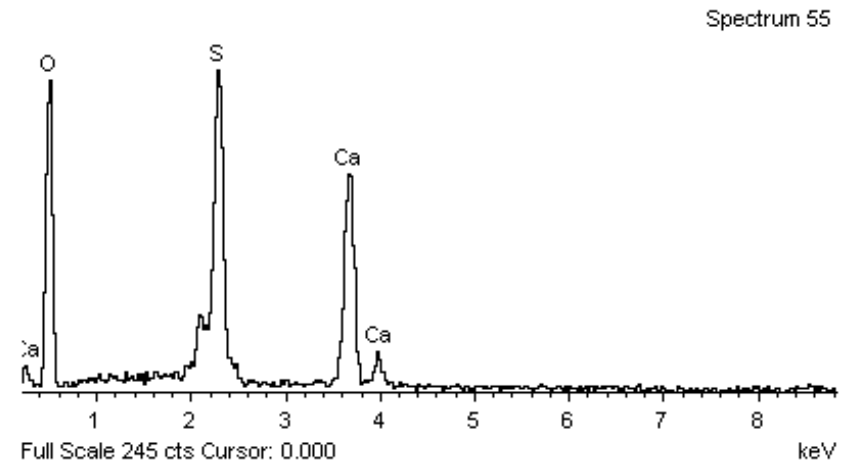

(a)

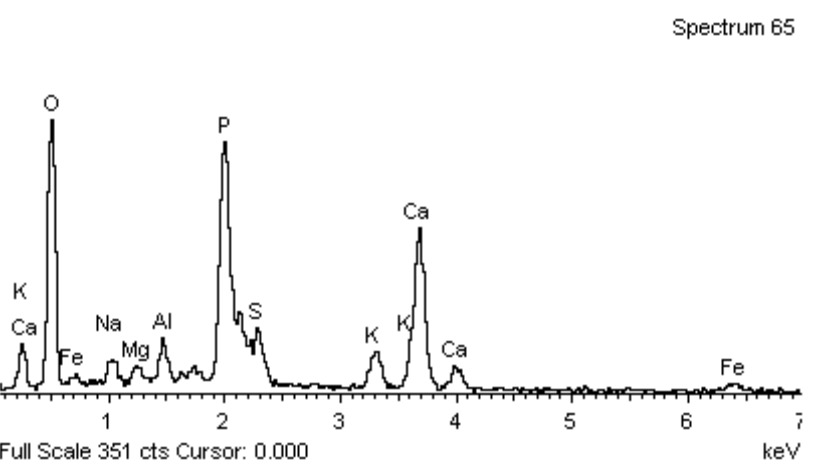

(b)

Fig. 2 Elemental analysis of precipitate products: (a) gypsum, (b) ettringite.

height) obtained from slices (total of 30 lines) for in situ investigated concrete samples are illustrated in Fig. 3.

With regard to the reference samples, higher percentage increase of both parameters was measured (13.3\% Rt, $15.4 \% \mathrm{Ra})$ when compared with the samples with coal fly ash (43.3\% Rt, 32.8\% Ra). The samples with $5 \%$ coal fly ash replacement seem to be more resistant against aggressive environment. This conclusion is supposed to be confirmed after completing the laboratory experiments results.

\subsection{The Weight Changes}

The weight changes of all samples in experiments were measured (Fig. 4). The increase of concrete samples weight was found in case of the experiment proceeding in situ (3.3\% in average for the sample with $5 \%$ coal fly ash replacement and $3.7 \%$ in average for the reference samples). The formation of the new surface products as a result of reaction between the constituents of concrete and microbial sulfuric acid is supposed to be the main reason of the weight increase. The presence of precipitated compounds on the concrete surface was confirmed by microscopy methods.

On the other hand the negligible decrease of concrete samples weight was observed in laboratory experiment ( $0.44 \%$ in average for the sample with $5 \%$ coal fly ash replacement and $0.34 \%$ in average for the reference samples). The decrease of the weight of the concrete samples may be the result of releasing of calcium compounds from cement matrix to the waste-water. These results correspond with our previous experiments [16] in which releasing of calcium compounds was confirmed by the rise of calcium concentrations in distilled water after concrete biocorrosion process. The calcium hydroxide releasing is responsible also for the rise of $\mathrm{pH}$ value of waste-water used in the laboratory experiments into alkali region (from 7.42 to 10.24). 


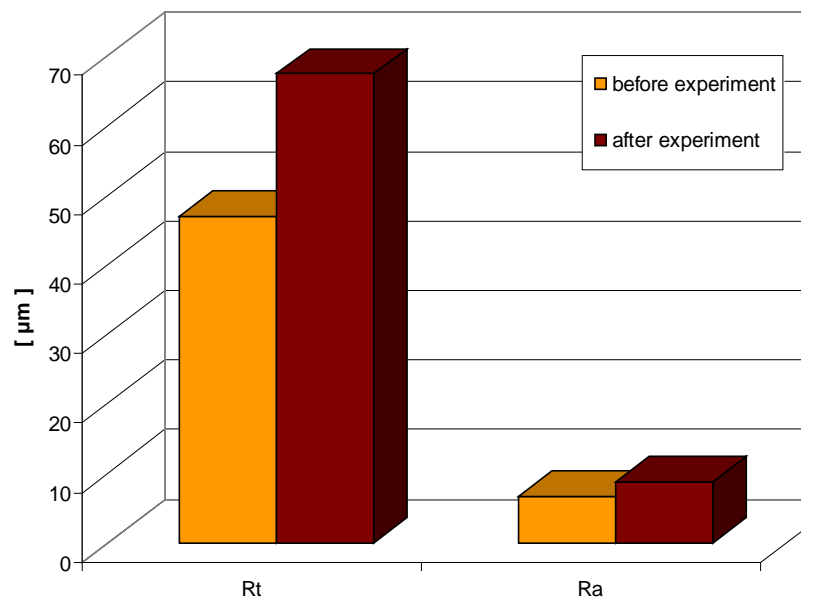

(a)

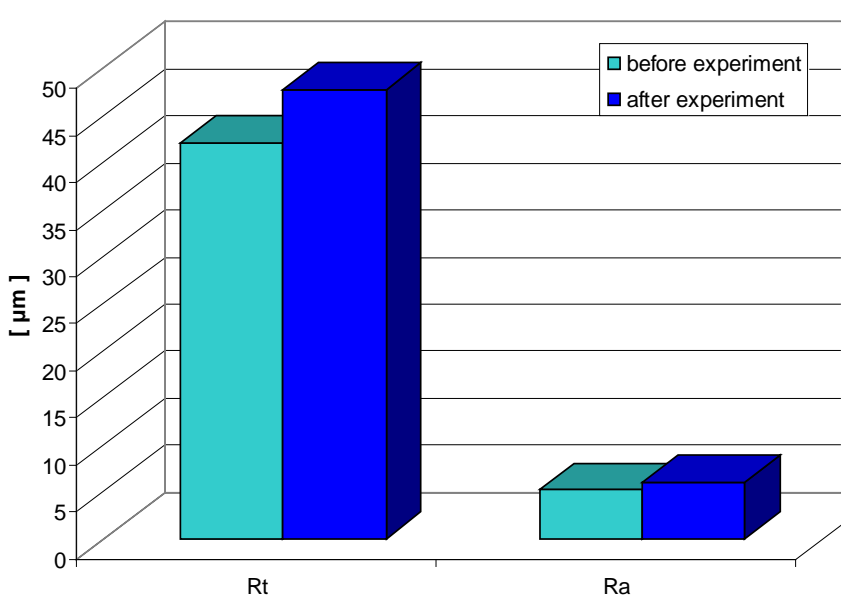

(b)

Fig. 3 (a) Roughness parameters changes of reference samples, (b) samples with $5 \%$ coal fly ash.

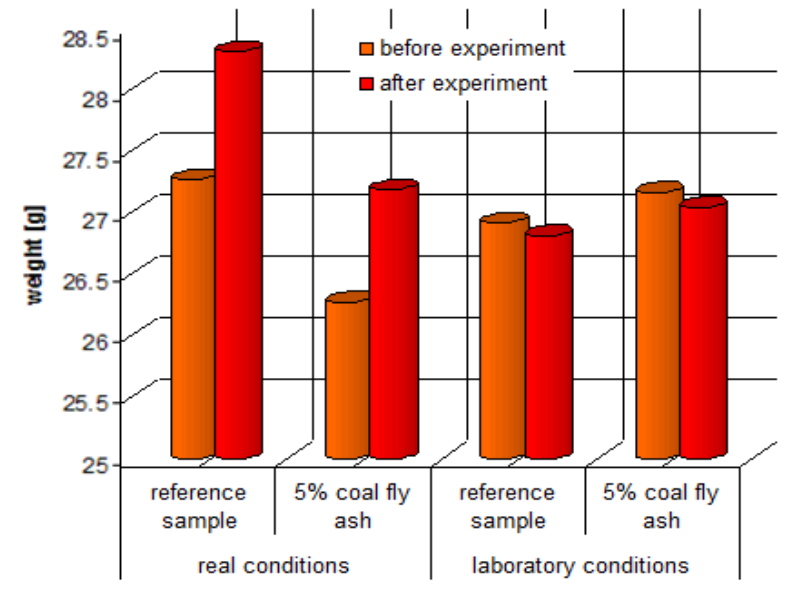

Fig. 4 Increase and decrease in concrete samples weight.

\section{Conclusion}

The resistance of cement composites with and without coal fly ash addition was investigated in this paper. The biodeterioration process was manifested by surface and weight changes of the cement composites samples. Different results of the tested samples in laboratory and in situ experiments were observed in relation to the weight changes. The presence of gypsum and ettringit as a surface precipitated product was confirmed in both the laboratory and in situ experiments for all samples. As predicted, the samples with $5 \%$ coal fly ash replacement seem to be more resistant to aggressive environment. For relevant conclusions more detailed investigation is in progress.

\section{Acknowledgements}

The research has been carried out within the Grant project No. 2/0166/11 Slovak Grant Agency for Science and within the projects NFP 262200220051 "Development of progressive technologies for utilization of selected waste materials in road construction engineering”, and NFP 26220120037 supported by the European Union Structural funds.

\section{References}

[1] C. Urzi and F. De Leo, Sampling with adhesive tape strips: An easy and rapid method to monitor microbial colonization on monument surfaces, Journal of Microbiological Methods 44 (1) (2001) 1-11.

[2] W. E. Krumbein, P. Brimblecombe, D. E. Cosgrove and S. Staniforth, Durability and Change: The Science, Responsibility, and Cost of Sustaining Cultural Heritage (1st ed.), Wiley, 1995, p. 326.

[3] H. Saito Czichos and L. T. Smith, Handbook of Material Measurement Methods, Springer, 2006, p. 1207.

[4] Th. Warscheid and J. Braams, Biodeterioration of stone: A review, International Biodeterioration and Biodegradation 46 (4) (2000) 343-368.

[5] D. P. Kelly and A. P. Wood, The Prokaryotes: A Handbook on the Biology of Bacteria (3rd ed.), NY: Springer, 2006, pp. 441-456.

[6] W. E. Krumbein and A. Gorbushina, The Effect of Airpollution on Cultural Heritage, US: Springer, 2009.

[7] C. Gaylarde, M. R. Silva and Th. Warscheid, Microbial impact on building materials: An overview, Materials and Structures 36 (2003) 342-352. 
[8] A. Bajza and I. Rousekova, Concrete Technology, JAGA, Bratislava, 2006 (in Slovak).

[9] M. Zajíček, Concrete admixtures-categories, properties and utilization, in: Proceedings of the Concrete Production, Banska Bystrica, 2008 (in Slovak).

[10] D. J. Roberts, D. Nica, G. Zuo and J. L. Davis, Quantifying microbially induced deterioration of concrete: Initial studies, International Biodeterioration \& Biodegradation 49 (2002) 227-234.

[11] J. Monteny, E. Vincke, A. Beeldens, N. De Belie, L. Taerwe, D. Van Gemert and W. Verstraete, Chemical, microbiological, and in situ test methods for biogenic sulfuric acid corrosion of concrete, Cement and Concrete Research 30 (2000) 623-634.
[12] V. Ondrejka Harbulakova, A. Estokova and N. Stevulova, Investigation of concrete biodeterioration in sewer pipes: Case study, Pollack Periodica 5 (1) (2010) 87-95.

[13] J. R. Postgate, The Sulphate Reducing Bacteria (2nd ed.), New York: Cambridge University Press, 1984.

[14] G. I. Karavajko et al., Biogeotechnology of Metals, Centre of Projects GKNT, Moscow, 1988.

[15] M. Tadahiro, N. Tsuguhiro, T. Kazue, K. Minako, H. Yasuo and N. Shuji, Interactions of nutrients, moisture and $\mathrm{pH}$ on microbial corrosion of concrete sewer pipes, Water Reseach 26 (1) (1992) 29-37.

[16] V. Harbuláková, A. Eštoková, A. Luptáková, N. Števulová and L. Sčigulinská, Microbially influenced corrosion of concrete, Chem. Listy 99 (2008) 1234-2345. 